\title{
Weed Management in Transplanted Rice-A Review
}

\author{
Priyanka Kabdal*, Tej Pratap and Vimal Raj Yadav \\ Department of Agronomy, College of Agriculture, G.B. Pant University of Agriculture and \\ Technology, Pantnagar, U.S. Nagar (263145), Uttarakhand, India \\ *Corresponding author
}

\section{A B S T R A C T}

\section{Keywords \\ Transplanted rice, Weeds, Chemical control, Yield \\ Article Info \\ Accepted: \\ 12 March 2018 \\ Available Online: \\ 10 April 2018}

\begin{abstract}
Rice is an important food crop extensively grown in India. Several factors are responsible for reducing the yield of transplant rice. However, weed infestation is the major threat to productivity of transplanted rice. Weeds by the virtue of their high adaptability and faster growth dominate the crop habitat and reduce the yield potential of the crop. These weeds could be controlled through manual and chemical methods. Manual method is though very common but cost intensive. Herbicides when applied alone is although economical but may have limitation of resistance development, shift in weed flora etc. Therefore, presently there is a need to use high efficacy herbicides in combination coupled with broad spectrum nature to control the complex weed flora in transplanted rice Also, the combination of herbicides increase the range of weed control, save time and reduce the cost of cultivation.
\end{abstract}

\section{Introduction}

Rice (Oryza sativa L.) is one of the most important food crops of India, contributing to about $40 \%$ of total food grain production. It plays a vital role in food security and livelihood for almost every household. The rice production in India in 2015-16 was 104.32 MT (Directorate of Economics and Statistics 2016-17). Out of the total 44 Mha area under rice cultivation, puddled rice culture occupies $56 \%$ (Anonymous, 2005).

Weeds remove a large amount of nutrients from soil. An estimate shows that weeds can deprive the crops by $47 \% \mathrm{~N}, 42 \% \mathrm{P}, 50 \% \mathrm{~K}$, $39 \% \mathrm{Ca}$ and $24 \% \mathrm{Mg}$ of their nutrient uptake as well as reduce the yield potential by harboring number of crop pests (Balasubramaniyan and Palaniappan, 2001). Hence successful weed control is essential for obtaining optimum yield of rice (Hussain et al., 2008; Kumar et al., 2007; Sathyamoorthy et al., 2004). Transplanted rice is the most common practice throughout the world. Normally puddling is done to reduce percolation losses, to control weeds and to make transplanting operation easier. Puddling and land submergence in transplanted rice provide a greater competitive advantage to crop over weeds as latter suffer due to unfavorable conditions for growth and development as compared to other methods of rice establishment. Thus, management of weeds is a fundamental requirement in transplanted rice cultivation. Weed free period 
during the critical period of competition is essential for obtaining optimum rice yield. This can be achieved by removing weeds manually, mechanically and through chemical sprays or by their combinations. Manual weeding is although effective and most common method, however, scarcity and high wages of labour particularly during peak period of agricultural operations make this method uneconomic. Further, it is possible only when the weed growth is to a size large enough for hand removal, by that time the weeds have done considerable damage to the crop. Further, mechanical method of weed management is also time taking, cost intensive, much tedious and also does not remove all the weeds. Weed management in transplanted rice through herbicide application may be the best suited option. It is practiced by farmers for past several years as it offers selective and economic control of weeds right from the beginning of crop growth and thus, minimize the crop-weed competition. It also save valuable time by covering more area in short period and is also cost effective. Raising cost of labour and their reduced availability has led to search for alternative methods such as herbicide use either alone or in combination with manual or mechanical weeding.

\section{Weed species in transplanted rice}

A broad spectrum of weed flora infests rice crop. The composition and competition by weeds is dynamic and is dependent on soil, climate, cropping and management factors. Various studies were conducted regarding weed flora all over India (Table 1) and there is a serious need to investigate problems regarding weeds and to plan their proper management.

\section{Crop weed competition}

Weed competition is one of the most important factors in limiting the yield of rice.
Competition between crop and weed begins when the supply of any of the growth factor is limiting and falls below the demand of both crop and weeds, when they grow in close proximity. Weeds having faster growth rate, accumulate large amount of biomass in a short period, which interferes with the growth of rice plants and ultimately affects the yield of rice crop.

Among the different weed species, grassy weeds pose greater competition. They have an extensive and fibrous root system. Similarly, sedges grow huge in number and cause serious competition for nutrients. The roots of the sedges also dominate the surface feeding zone and obstruct nutrient flow to crop roots. weeds interferes with rice growing by competing for one or more growth limiting resources i.e nutrients, water, space, light and carbon dioxide, because of the limited supply of these valuable elements, their association therefore, leads to competition for these elements for the survival. Generally, one-third duration of the crop period should be maintained weed free. The critical crop weed competition from 28-45 DAT in transplanted rice was reported by various workers (Raju and Reddy, 1995; Nandal et al., 1999 and Singh et al., 2003). However it was reported that crop and weed competition up to 60 days stage of transplanted rice resulted in $72 \%$ reduction in grain yield (Singh et al., 2004). Dhammu and Sandhu (2002) observed that Cyperus iria competition for the first 30 days caused less than one-fourth $(12.9 \%)$ of the total yield loss in transplanted rice while competition for 40 days resulted in more than half $(43.5 \%)$ of the total yield loss due to the weeds. Singh et al., (2005) found that grasses constituted $14.1 \%$, sedges $71.4 \%$ and broad-leaf weeds $14.5 \%$ of the total weed population in rice crop at 30 days stage. Mukherjee et al., (2008) noticed that 20-40 days after transplanting was the most critical period of crop weed competition and found that weedy situation throughout the 
crop growth caused yield reduction to the tune of $57-61 \%$ in transplanted rice.

\section{Yield reduction by weeds in rice}

Considerable losses in the grain yield of rice due to infestation of weeds have been reported by different workers in the country. Janiya (2002) reported that grain yield losses due to weeds in lowland rice field ranges $20 \%$ to $60 \%$ and $30 \%$ to $80 \%$ in transplanted and direct-seeded rice, respectively. Reddy et al., (2003) from Hyderabad noticed that Cyperus spp., Paspalum spp., Caesulia axillaris, Rotala densiflora and Monocharia vaginalis caused 28-40\% reduction in yield of transplanted rice. Hossain et al., (2010) from Ranchi reported that the weed population as well as dry matter was reduced in transplanted rice with higher weed control efficiency resulting in higher grain yield.

\section{Methods of weed control}

Weed control methods are grouped into cultural, manual, mechanical, chemical and biological methods. Each of them has their own advantage and disadvantage and single method is rarely found effective so, summarized reviews are given below particularly for manual weeding and chemical methods of weed control in transplanted rice.

\section{Manual weeding}

The earliest ways of weed control in rice were cultural methods. In spite of labor intensive hand weeding is still most common direct weed control method in rice in India using bare hands and hand tools. These practices are only effective when weeds attain height to provide better grip for uprooting Bhan et al., (1980). Rekha et al., (2002) reported that twice hand weeding resulted in lower weed density as compared to herbicides and untreated control. Kathirvelan and Vaiyapuri
(2003) recorded that hand weeding at 20 and 40 DAT resulted in significantly lower weed population $\left(2.7 \mathrm{~m}^{-2}\right)$ and weed dry matter production $(155.7 \mathrm{~kg} / \mathrm{ha})$ as compared to herbicidal treatments. Halder and Patra (2007) from Orissa reported that twice hand weeding at 20 and 40 DAT resulted in the minimum weed population and dry weight and the highest weed control efficiency at both the stages. Jayadeva et al., (2009) from karnataka observed that Hand weeding twice (20 and 24 DAT) recorded lower weed dry weight and higher mean grain and straw yield in rice.

\section{Chemical control}

For effective weed control in transplanted rice, judicious application of herbicide as pre and post-emergence is given below.

\section{Bispyribac sodium}

Bispyribac sodium belongs to the Pyrimidinal Thiobenzoates group of herbicides. It is recently introduced herbicide have the similar mode of action as the Sulfonylureas. It is highly selective, post-emergence, low mammalian toxic and low dose (15-40g/ha) require herbicide so become popular now a days to control weed in rice growing area either transplanting or direct seeded (Das, 2008). The highest net benefit was obtained by the application of bispyribac sodium 100 SC followed by Ethoxysulfuron 60 WG treatments while the lowest net benefit was provided by control (weedy check). NO doubt, the result of hand weeding is significantly better as it is time consuming and laborious hence cannot be recommended at large scale (Hussain et al., 2008). Veeraputhiran and Balasubramanian (2010) conducted an experiment during 2010 and 2011at Madurai (Tamil Nadu) recorded that the total weed population and dry weight under post emergence application of bispyribac- $\mathrm{Na}$ at 25 $\mathrm{g} / \mathrm{ha}$ was on par with its higher doses of 35 
and $50 \mathrm{~g} / \mathrm{ha}$ while weed control efficiency and weed index at its lower dose $(25 \mathrm{~g} / \mathrm{ha})$ were comparable with the higher doses i.e., 35 and $50 \mathrm{~g} / \mathrm{ha}$. Post-emergence application of bispyribac sodium at $25 \mathrm{~g} / \mathrm{ha}$ recorded significantly higher grain yield (6838 and $6510 \mathrm{~kg} / \mathrm{ha}$ ) during 2010 and 2011, respectively over pre emergence application of butachlor at $1500 \mathrm{~g} / \mathrm{ha}$ but remained at par with its higher doses viz., 35 and $50 \mathrm{~g} / \mathrm{ha}$, twice hand weeding and weed free. Parthipan and Ravi (2016) found that post emergence application of bispyribac sodium at $25 \mathrm{~g}$ ai/ha at 15 DAT followed by hand weeding at 45 DAT produced higher grain yield and was at par with two hand weedings due to lower crop weed competition.

\section{Pretilachlor}

Pretilachlor belongs to Acetamides group of herbicides. It is selective systemic herbicide absorbed primarily by the germinating root with translocation throughout the plant. It is applied either as pre-emergence or early post emergence to control the annual grasses and broad leaf weeds but mainly used as a grass killer in transplanted rice.

It is selective broad spectrum pre- emergence herbicide for use in early season in transplanted rice with cell division inhibitor as its mode of action. It controls grassy and sedges weed species viz. E. crus-galli, E. colona, Leptochola chinensie, $C$. rotundus, $C$. iria, $C$ difformis, and Fimbristylis millacea in rice fields. Pretilachlor is supplied with trade name a surfactant under the trade name sofit but the trade name Rifit does not contain extra surfactant. Bhowmick et al., (2000) found that pretilachlor at $0.8 \mathrm{~kg} / \mathrm{ha}$ effectively controlled the weeds in transplanted rice and recorded the maximum grain and straw yields which were at par with hand weeding. A $40 \%$ pretilachlor + bensulfuron-methyl WP used at 675-900 g/ha either at 0 or 4 days after rice sown was very effective against E. crusgalli and L. chinensis, with more than $95 \%$ total efficacy (Jinhao et al., 2000). Pretilachlor in combination with safener and hand weeding resulted in the lowest weed density and dry matter and highest weed control efficiency, grain yield and number of panicles in direct seeded puddled rice (Mhajan et al., 2003). Shultana et al., (2011) recorded lowest weed biomass and significantly highest weed control efficiency $(86.01 \%)$ with the application of pretilachlor $50 \mathrm{EC}$ at 1 lit/ha under Gazipur, Bangladesh situation.

\section{Penoxsulam}

Penoxsulam is a triazolopyrimidine sulfonamide herbicide used to control grasses, broad leaf and sedges weeds in rice crop. It is early post-emergence herbicide absorbed mainly via leaves and secondarily via roots. It is a new acetolactate synthase (ALS) inhibitor herbicide for post-emergence control of annual grasses, sedges and broad leaf weeds in rice culture (Jabusch and Tjeerdema, 2005).

It is commercialized in European union as oil dispersion (OD) containing $20 \mathrm{~g} / \mathrm{l}$, requiring no additional adjuvant. It has a favourable toxicological and environmental profile that controls Echinochola spp., major broad leaf weeds and sedges. Pal et al., (2009) found that penoxsulam $(24 \mathrm{SC})$ at $0.0225 \mathrm{~kg}$ a.i./ha applied at 8-12 days after transplanting was most effective in reducing the weed population in broad spectrum as well as of weeds growth. This treatment also gave the maximum grain yield (35.3 q/ha) and straw yield $(47.3 \mathrm{q} / \mathrm{ha})$ of rice resulting in lowest weed index (5.6\%). Yadav et al., (2010) from Karnal reported that penoxsulam at $25 \mathrm{~g} / \mathrm{ha}$ as pre-emergence (3 DAT) and $22.5 \mathrm{~g} / \mathrm{ha}$ as postemergence (10-12 DAT) application provided satisfactory control of all types of weeds consequently resulting in grain yield of transplanted rice similar to weed free plot. 
Table.1 Major weed flora of transplanted rice in different regions

Major weed flora

Echinochola crus-galli, Paspalum distichum and Caesulia axillaris

Cyperus iria, Sphenoclea zeylanica, Leptochloa chinensis, Fimbristylis miliacea and Eclipta alba

E.colona, E.crus-galli, Cyperus rotundus, Cyperus difformis, Fimbristylis miliacea, Ludwigia parviflora, and Ammania baccifera

E.crusgalli, Leersia hexandra, Marsilea quadrifolia

Echinochloa crus-galli, E. colona, Cyperus iria, C. rotundus, Fimbristylis miliacea, Ammania baccifera, Marsilea quadrifolia and Potamogeton distinctus

Echinochola glabrescens, E. colona (L.), Ammania baccifera (L), Euphorbia spp., Fimbristylis miliacea (L.), Cyperus rotundus (L.), Cyperus iria (L.) and Cyperus difformis (L.)

Cyperus difformis, Fimbristylis miliacea, Scripus spp., C. procerus, Echinochola colona, Panicum tripheron, Ludwigia parviflora, Spinanthus acemella, Rotala verticillaris, Lindernia veronicaefolia and Glinus oppositifolia

Echinocloa crusgalli, Cynodon dactylon, Echinocloa colona, Cyperus rotundus and Amaranthus viridis

Digitaria sanguinalis, Echinochola crus-galli, E.colona, Panicum repens, Fimbristylis miliacea, Cyperus rotundus, Cyperus iria, Cyperus difformis, Ammania baccifera, Ludwigia parviflora, Eclipt prostrate, Eclipta alba, Lippa nodiflora Nich, Marsilea quadrifolium, Sphenoclea zeylanica, and Commelina benghalensis

Cyperus rotundus, Cynodon dactylon, Echinochloa colonum, Ceasulia axillaris, Phyllanthus niruri and Parthenium hysterophorus

Echinochloa crusgalli, Echinochloa colonum, Leptochloa, Chinensis

Cyperus difformis, Cyperus iria, Fimbristylis miliacea, Eclipta alba, Ammania baccifera, Bergia capensis and Ludwigia parviflora

Echinichloa sp., Panicum repens, Cynodon doctylon, Leptochloa chinensis, Eclipta alba, Ludwigia parviflora and Cyperus sp.

\begin{tabular}{|c|c|}
\hline Place & Reference \\
\hline Pantnagar & Sarkar (2001) \\
\hline Karnal & $\begin{array}{l}\text { Chopra and Chopra } \\
\text { (2003) }\end{array}$ \\
\hline Varanasi & $\begin{array}{l}\text { Mukherjee and Singh } \\
\text { (2004) }\end{array}$ \\
\hline West Bengal & Ghosh and Ghosh (2005) \\
\hline Kashmir & Singh et al., (2007) \\
\hline Karnal & Yadav et al., (2009) \\
\hline $\begin{array}{l}\text { Banglore } \\
\text { Karnataka }\end{array}$ & $\begin{array}{l}\text { Ramchandra et al., } \\
(2010)\end{array}$ \\
\hline Varanasi & $\begin{array}{l}\text { Sharma and Singh } \\
(2010)\end{array}$ \\
\hline Orissa & Patra et al., (2011) \\
\hline Varanasi & Singh et al., (2014) \\
\hline Tamil Nadu & $\begin{array}{l}\text { Parthipan and Ravi } \\
\text { (2016) }\end{array}$ \\
\hline $\begin{array}{l}\text { Raichur, } \\
\text { Karnataka }\end{array}$ & Ramesha et al., (2017) \\
\hline
\end{tabular}

Penoxsulam was particularly better against broad-leaf weeds and sedges than the application of butachlor and pretilachlor. Nath and Pandey (2013) application of penoxsulam @ $25 \mathrm{~g} / \mathrm{ha}$ significantly reduce the weed population and dry weight of weeds.

Ramesha et al., (2017) reported that application of penoxsulam @ $83.3 \mathrm{ml} / \mathrm{ha}$ controlled all types of weeds and increased the grain yield of rice

\section{Pyrazosulfuron}

Pyrazosulfuron is the member of the pyriimidinyl pyrazolesulfonylureas group of herbicide and was widely use in North East Asian countries like Japan and Korea, recently introduced in India (in rice belt) for weed control in rice nurseries as well as transplanted and direct seeded rice. It is a systematic type in nature and applied as preemergence and early post-emergence 
herbicide. It is highly selective to rice crop so also called as rice herbicide. It control grasses, sedges and broad leaf weed in rice. Grasses includes Echinochloa colona, Panicum spp., sedges includes Fimbristylis millacea, Cyperus spp., and broad leaf weeds includes Ludwigia parviflora, Marsilea quadrifolium, Alternanthera sesselis etc. Pyrazosulfuron is absorbed by roots or leaves and translocated to meristem which inhibits ALS/AHAS enzyme catalyzing the biosynthesis of three essential branched-chain amino acid, namely leucine, valine and isoleucine they stops cell division of roots and check the plant growth. It has got very low persistence in soil and ground water with a half-life value of 7-10 days. Thus it is safe to ecosystem. Das (2008) found that the application of Pyrazosulfuron in general increase vigor of rice plants in terms of more number of tillers and better grain filling resulting in higher yield. Revathi et al., (2010) from Coimbatore (Tamil Nadu) found that the application of pyrazosulfuron ethyl 30 $\mathrm{g} / \mathrm{ha}$ at 3DAT reduce the total weed density and dry weight.

\section{Chlorimuron-ethyl + Metsulfuron-methyl}

Chlorimuron-ethyl (10\%) + Metsulfuronmethyl $(10 \%)+0.2 \%$ surfactant (Ready-mix) belong to the Sulfonylureas group of the herbicide. It is a herbicidal formulation applied as post-emergence to control broad leaf weed in rice field. Mukherjee and Singh (2005) found superiority in grain yield and net monetary returns with the appliances of chlorimuron-ethyl + metsulfuron-methyl +2 , 4-D for transplanted rice over other weed control means. Patra et al., (2011) observed that application of chlorimuron-ethyl + metsulfuron-methyl $0.004 \mathrm{~kg} / \mathrm{ha}$ mixed with butachlor $0.938 \mathrm{~kg} / \mathrm{ha}$ at 3 days after transplanting (DAT) was at par with hand weeding twice at 20 and 40 DAT in controlling weeds and higher grain yield. This application increased the grain yield by $45.1 \%$ over the unweeded check. Sah et al., (2012) observed that pre-emergence application of chlorimuron-ethyl + metsulfuron-methyl $(0.025 \mathrm{~kg} / \mathrm{ha})$ at 3 DAT $\mathrm{fb}$ sequential application of $2,4-\mathrm{DEE}(0.5 \mathrm{~kg} / \mathrm{ha})$ at $20 \mathrm{DAT}$ was found most effective in minimizing weed population and their dry matter accumulation and increasing weed control efficiency and grain yield next to two hand-weeding, both were at par. $80.1 \%$ and $77.7 \%$ increase in grain yield was recorded in two hand weeding and chlorimuron-ethyl + metsulfuron-methyl followed by $2,4-\mathrm{DEE} \quad(0.025+0.5 \mathrm{~kg} / \mathrm{ha})$, respectively over weedy check.

\section{Ethoxysulfuron}

Ethoxysulfuron it belong to the Sulfonylureas group of herbicide and acts as Acetolactate synthase inhibitor (ALS). It acts by reducing the levels of three branched -chain aliphatic amino acids. It is highly selective, postemergence low mammalian toxic and low dose (10-40 g/ha) require herbicide so gaining popularity to control weed in transplanted rice. Cheema et al., (2005) reported that Ethoxysulfuron (Sunrice, 15WG) alone @ 25 and $30 \mathrm{~g}$ a.i per hectare reduced total weed density and dry weight in the range of 66.29 to $73.95 \%$ and 69.23 to $85.71 \%$ respectively. Shahbaz et al., (2007) found there was lowest dry matter accumulation by Alternanthara triandra under the application of Ethoxysulfuron that might be due to better killing capacity of ethoxysulfuron against broad-leaf weeds.

\section{Pretilachlor $(6 \%)+$ Bensulfuron $(0.69 \%)$}

Bensulfuron-methyl, a member of sulfonylurea herbicides, is a broad-spectrum herbicide for the control of broadleaf-weeds and sedges in the rice fields. As a selective herbicide for direct seeding and mechanical transplanting rice fields, bensulfuron is active 
at a rate as low as $30-70 \mathrm{~g}$ ai/ha and has a good herbicidal activity on most annual and perennial weeds in the rice fields. This is used as a mixture with pretilachlor, butachlor, mefenacet and other grass-killing herbicides for the effective control of grassy weeds. The mode of action by bensulfuron-methyl is similar to other sulfonylurea herbicides. The primary site of bensulfuron-methyl is the inhibition of ALS (acetolactate synthase) which is an important acid biosynthesis. Secondary effects of the cell division and retardation of plant growth (Ray, 1984 and Takeda et al., 1985). This study was to examine and compare the physiological responses of differences in weeds showing different susceptibility to sulfonylurea herbicide which is known for representative herbicide in paddy fields. Singh et al., (2005) from pantnagar reported that Bensulfuromethyl at 30 to $60 \mathrm{~g} / \mathrm{ha}$ applied alone or as tank mixture with butachlor at $1.0 \mathrm{~kg} / \mathrm{ha}$ reduced the density of all the sedges as well as Caesulia axillaris and Commellina benghalensis. At higher doses of bensulfuion methyl (50 and $60 \mathrm{~g} / \mathrm{ha}$ ), there was almost complete control of sedges and non-grassy weeds. The differences in grain yields due to various doses of bensulfuron-methyl were non-significant and yields were at par with weed free treatment. Shekhra et al., (2011) found that application of bensulfuron methyl + pretilachlor (6.6\%) @ $0.06+0.60 \mathrm{~kg} \mathrm{a.i} / \mathrm{ha}$ + one intercultivation at 40 DAT recorded significantly lower weed population and weed dry weight and higher grain yield. This was at par with Bensulfuron methyl+ pretilachlor (6.6\%)@ 0.06\%+0.60 kg a.i/ha.

\section{Economics}

Weed management should be practiced by least expensive available technology that does not interfere with other phases of crop production or human activities. Any weed control measure should be used only when its results are expected to be more economically beneficial then the results of not using any control measures (Moody, 1993). Marginal benefit cost ratio and net returns are the best ways to assess the economic viability of a particular weed control treatment. Hand weeding is the predominant method of weed control. However low cost chemicals are being effectively used (De Dutta, 1974) often in combination with limited hand weeding, this appears to be economical in many situation. Pretilachlor and butachlor recorded good net return. Pretilachlor $625 \mathrm{~g} / \mathrm{ha}$ was reported more economical as compared to butachlor $1250 \mathrm{~g} / \mathrm{ha}$ getting good yield as well as cost benefit ratio (Sharma and Upadhyay, 2002). Chlorimuron-ethyl + metsulfuronmethyl fb 2,4-DEE (0.025 fb $0.5 \mathrm{~kg} / \mathrm{ha})$ recorded highest net returns (Rs18070/ha) and benefit: cost ratio (1.99).

Veeraputhiran and Balasubramanian (2012) recorded higher economic benefits like net income and benefit cost ratio with the postemergence application of bispyribac-Na at $25 \mathrm{~g} / \mathrm{ha}$ than all the other weed management treatments under Madurai situations.

Weeds pose a major problem in rice production as they not only compete with crop but also hinder the quality of rice produce. Any delay in weeding will lead to increased weed biomass as a result there is drastic reduction in total yield of the crop. Therefore, to avert the economic losses a broad spectrum weed control should be affective during the life cycle especially during the critical stages of rice crop. Effective control of weeds in rice could be achieved with pre-emergence herbicide use of Pretilachlor, Penoxsulam, Pyrazosulfuron. Among the post emergence herbicides use of Chlorimuron-ethyl + Metsulfuron-methyl, Ethoxysulfuron, Bispyribac sodium gives promising results. But for the effective control of weeds combination of pre and post 
emergence herbicides is most effective method foe broad spectrum weed control in transplanted rice.

\section{References}

Anonymous, 2005. Atlas of Rice and World. Rice Statistics http://www.irri.org/ science/ricestat/index.asp.

Balasubramanian, P. and Palaniappan S.P. 2001. Principles and practices of Agronomy. Agrobios Publishing co. Pvt. Ltd., New Delhi: 306-364.

Bhan, V. M., Maurya, R.A. and Negi, S.S. 1980. Characterization of critical stages of weed competition in drilled rice. Indian J. of Weed Sci. 12(1): 75-79.

Bhowmik, M.K., Ghosh, R.K. and Pal, D. 2000. Bio-efficacy of new promising herbicides for weed management in summer rice. Indian J. of Weed Sci. 32(1\&2): 32-58.

Cheema et al., 2005. Sorgaab for weed control in Transplanted Fine Rice (Oryza sativa L.) Int. J. Agri. Biol., Vol.7 No. 6.

Chopra, N.K. and Chopra, N. 2003. Effect of doses and stages of application of pyrazosulfuron-ethyl on weeds in transplanted rice. Indian J. of Weed Sci. 35: 27-29.

Das, T. K. 2008. Weed science basic and application, Jain Brothers.

De Dutta, S. K. 1974. Weed control in rice: Present status and future challenge, Phillippines Weed Sci. Bull., 1(1): 1-16.

Dhammu, H. S. and Sandhu, K. S. 2002. Critical period of Cyperus iria L. competition in transplanted rice. Proc. 13th Australian Weeds Conference: weeds "threats now and forever", Sheraton Perth Hotel, Perth, Western Australia, 8-13 September 2002: pp. 7982.

Directorate of Economics and Statistics 20162017. Directorate of Economics and Statistics DAC\&FW, Department of Agriculture, Cooperation and Farmers Welfare Ministry of Agriculture and Farmers welfare, Govt. of India.
Ghosh, P. and Ghosh, R. K. 2005. Bio-efficacy and phytotoxicity of clomazone $+2,4-\mathrm{D}$ for weed control in transplanted rice. Indian J. of Weed Sci. 37 (1\&2): 107-108.

Halder, J. and Patra, A.K. 2007. Effect of chemical weed control methods on productivity of transplanted rice (Oryza sativa). Indian J. of Agronomy 52 (2): 111-113.

Hossain, A., Duary, B. and Mondal, D. C. 2010. Effect of weed management under different methods of rice establishment in the lateritic soil of West Bengal. Biennial Conference on "Recent Advances in Weed Science Research- 2010", Feb. 2526, 2010, IGKV, Raipur (Chhattisgarh). pp. 63.

Hussain, S., A.M. and Aslam. 2008. Weed management in direct seeded rice. $J$. Anim. Pl. Sci. 18 (2-3): 86-88.

Jabusch, T. W. and Tjeerderma, R. S. 2005. Partitioning of penoxsulam-a new sulfonamide herbicide. J. Agric. Food Chem. 53: 7179-7183.

Janiya, J. D. 2002. Weed management in major crops in the Philippines. Los Baños, Laguna, Philippines: In Weed Science Society of the Philippines. Yield losses, major weed species, and suggested management systems in selected major crops: rice, pp. 17-37.

Jayadeva, H. M., Bhairappanavar, S. T., Somashekharappa, P. R. and Rangaswamy, B. R. 2009. Efficacy of azimsulfuron for weed control in transplanted rice. Indian $J$. of Weed Sci. 41(3\&4):172-175.

Jinhao, H., Xiaojun, Z., Yujian, S., Zhaojiang M. and Huanzheng B. 2000. Occurrence of weeds in early direct seeded rice fields and their control in Jinhua, Zhejiang. Acta Agriculturae Zhejiangensis. 12(6): 331334.

Kathirvelan, P. and Vaiyapuri, V. 2003. Relative efficacy of herbicides in transplanted rice. Indian J. of Weed Sci. 35(3\&4): 257-258.

Kropff, M.J. 1993. Eco-Physiological models for crop-weed competition. In Modelling 
crop-weed interactions, eds M. J. Kropff and Van Laar H.H. X: X, pp. 25-32.

Kumar, A., Shivay YS and Pandey J. 2007. Effect of crop establishment methods and weed control practices on weed dynamics, productivity, nutrient removal by weeds visà-vis crop and quality of aromatic rice (Oryza sativa). Indian J. of Agri. Sci. 77: 179-183.

Mahajan, G., Boparai, B.S., Brar, L.S. and Sardana, V. 2003 Effect of pretilachlor on weeds in direct seeded puddled rice. Indian J. of Weed sci. 35 (1-2): 128-130.

Moody, K. 1993. Weed control in wet seeded rice. Experimental Agri. 29(4): 393-403.

Mukherjee, D. and Singh, R. P. 2004. Efficacy of certain low doses herbicides in medium land transplanted rice. India J. of Weed Sci. 36(1\&2): 47- 49.

Mukherjee, D. and Singh, R.P. 2005. Effect of microherbicide on weed dynamics, yield and economics of transplanted rice (Oryza sativa). Indian J. of Agronomy 50(4): 292-295.

Mukherjee, P.K., Sarkar, A. and Maity, S.K. 2008. Critical period of crop-weed competition in transplanted and wetseeded kharif rice (Oryza sativa L.) under tarai conditions. Indian J. of Weed Sci. 40: $147-152$.

Nandal, D.P., Hariom and Dhiman, S.D. 1999. Management of weeds with herbicides in transplanted rice. Indian J. of Weed Sci. 31(1\&2): 75-77.

Nath, C.P and Pandey P.C. 2013. Evaluation of Herbicides on grain yield and Nutrient uptake in Rice (Oryza sativa L.). Bioinfolet 10(1B):282-287.

Pal, S., Banerjee, H. and Mandal, N.N. 2009. Efficacy of low dose of herbicides against weeds in transplanted kharif rice (Oryza sativa L.). J. of Plant Protection Sci. 1(1): 31-33.

Parthipan, T. and Ravi, P. 2016. Productivity of transplanted rice as influenced by weed control methods. African J. of Agri. Res. 11(16):1445-1449.

Patra, A.K., Halder, J., and Mishra, M.M. 2011. Chemical weed control in transplanted rice in Hirakud command area of Orissa. Indian J. of Weed Sci. 43(3\&4): 175-177.

Raju, R. A. and Reddy, M. N. 1995. Performance of herbicide mixture for weed control in transplanted rice. Indian J. Weed Sci. 27: 106-107.

Ramchandra, C., Denesh, G.R. and Sydanwarulla. 2010. Weed management practices in transplanted rice by using glyphosate. Biennial Conference on "Recent Advances in Weed Science Research-2010", February 25-26, 2010, Indira Gandhi Krishi Vishwavidyalaya, Raipur (Chhatisgarh). pp. 68.

Ramesha, Y.M., Bhanuvally, M., Gaddi, A.K., Krishamurthy, D. and Umesh, M.R. 2017. Efficacy of herbicides against weeds in transplanted Rice (Oryza sativa L.). Int. J. of Plant and Soil sci. 18(1): 1-8.

Ray T.B. 1984. Site of action of Chlorsulfuron Plant Physiol. 75:827-831.

Reddy, C.N., Reddy, M.D. and Devi, M.P. 2003. Effect of cinosulfuron on weeds and transplanted kharif rice. Indian J. of Weed Sci. 35(1\&2): 117-118.

Rekha, K. B., Raju, M. S. and Reddy, M. D. 2002. Effect of herbicides in transplanted rice. Indian J. Weed Sci. 34(1-2): 123125.

Revathi, M., Prabhakaran, N. K. and Chinnusamy, C. 2010. Establishment techniques and weed management practices in puddle lowland rice. Biennial Conference on "Recent Advances in Weed Science Research- 2010", Feb. 2526, 2010, IGKV, Raipur (Chhatisgarh). pp. 71-72.

Sah, A., Ansari, A. M. and Ahmad, E. 2012. Effect of herbicides on weeds, yield attributes, yield and economics of transplanted rice (Oryza sativa L.). Prog. Agric. 12(2):337 -343.

Sarkar, N.C. 2001. Studies on chemical weed control in transplanted rice (Oryza sativa). M.Sc. Ag. (Agronomy) Thesis G.B. Pant University of Agriculture and Technology, Pantnagar. pp: 108-112.

Satyamoorthy, N.K Mahendran S, Babu R and Ragavan T. 2004. Effect of integrated 
weed management practices on total dry weight, nutrient removal of weeds in ricerice wet seeded system. Journal of Agronomy 3(4): 263-267.

Shahbaz et al., 2007. Weed Management in Direct seeded rice crop. Pak. J. Weed Sci. Res. 13(3-4): 219-226.

Sharma, R. and Upadhyaya, V. B. 2002. Bioefficacy of acetachlor in transplanted rice. Indian J. of Weed Sci. 34 (3\&4): 184186.

Sharma, S.N. and Singh, R.K. 2010.Weed management in rice wheat cropping system under conservation tillage. Indian J. Weed Sci. 42(1\&2): 23-29.

Shekhra et al., 2011. Growth and yield of Aerobic rice as influenced by integrated weed Management practices. Indian J. of Weed Sci. 42(3\&4): 180-183.

Shultana, R., Al-Mamun, Md. A., Rezvi, S. A. and Zahan, M. S. 2011. Performance of some pre emergence herbicides against weeds in winter rice. Pak. J. Weed Sci. Res. 17(4):365-372.

Singh, A.K., Singh, M.K., Prasad, S.K. and Sakarwar, P. 2014. Sequential herbicide application and nitrogen rates effect on weeds in direct seeded rice (Oryza sativa L.). The Ecoscan 8(3\&4):249-252.

Singh, G., Singh, V. P., Singh, M. and Singh, S.P. 2003. Effect of anilofos and triclopyr on grassy and non-grassy weeds in transplanted rice. Indian J. of Weed Sci. 35 (1\&2): 30-32.

Singh, G., Singh, V.P. and Singh, M. 2004. Effect of almix and butachlor alone and in combination on transplanted rice associated weeds. Indian J. Weed Sci. 36(1\&2): 64-67.

Singh, P., Singh, P., Singh, R. and Singh, K.N. 2007. Efficacy of new herbicides in transplanted rice (Oryza sativa) under temperate conditions of Kashmir. Indian J. of Weed Sci. 3(3 \&4): 167-171.

Singh, S., Singh, G., Singh, V. P. and Singh, A. P. 2005. Effect of establishment methods and weed management practices on weeds and rice in rice-wheat cropping system. India J. of Weed Sci. 37 (1\&2): 51-57.

Takeda, S., T.B Sweetser, D.L. Erbes, and T. Yuyama. 1985. Mode of selectivity of Londex herbicide (DPX-F5384) in paddy rice. Proc. $10^{\text {th }}$ APWSS Conf. 1: 156-161.

Veeraputhiran, R. and Balasubramania, R. 2012. Evaluation of new post emergence herbicide bispyribac sodium for transplanted rice. Binneal Conference of Indian Society of Weed Science on "Weed threat to Agriculture, Biodiversity and Environment", April 19-20. KAU, Thrissur (Kerala). pp. 252.

Yadav, D. B., Yadav, A. and Punia, S. S. 2009. Evaluation of Bispyribac-sodium for weed control in transplanted rice. Indian J. of Weed Sci. 41(1\&2): 23-27.

Yadav, D.B., Punia, S.S. and Yadav, A. 2010. Efficacy of Bispyribac-sodium, azimsulfuron and penoxsulam for post emergence weed control in transplanted rice. Biennial conference on "Recent Advances in Weed Science Research2010”, Feb. 25-26, 2010, Indira Gandhi Krishi Vishwavidyalaya, Raipur (Chattisgarh). pp. 65.

\section{How to cite this article:}

Priyanka Kabdal, Tej Pratap and Vimal Raj Yadav. 2018. Weed Management in Transplanted Rice-A Review. Int.J.Curr.Microbiol.App.Sci. 7(04): 1660-1669. doi: https://doi.org/10.20546/ijcmas.2018.704.187 